doi: 10.1016/j.gca.2004.03.002

\title{
Assessing scleractinian corals as recorders for paleo-pH: Empirical calibration and vital effects
}

\author{
B. Hönisch,,${ }^{1} *$ N. G. Hemming, ${ }^{1,2}$ A. G. Grottoli, ${ }^{3}$ A. Amat,${ }^{4}$ G. N. Hanson, ${ }^{5}$ and J. Bijma ${ }^{6}$ \\ ${ }^{1}$ Lamont-Doherty Earth Observatory of Columbia University, NY 10964-8000, USA \\ ${ }^{2}$ The School of Earth and Environmental Sciences, Queens College NY 11367-1597, USA \\ ${ }^{3}$ University of Pennsylvania, PA 19104-6316, USA \\ ${ }^{4}$ Bermuda Biological Station for Research, GE 01, Bermuda \\ ${ }^{5}$ State University of New York at Stony Brook, NY 11794-2100, USA \\ ${ }^{6}$ Alfred Wegener Institute for Polar and Marine Research, D-27570 Bremerhaven, Germany
}

(Received August 18, 2003; accepted in revised form March 2, 2004)

\begin{abstract}
Laboratory experiments on the branching, symbiont-bearing coral genus Porites and Acropora have been carried out to determine the dependence of the skeletal boron isotopic composition $\left(\delta^{11} \mathrm{~B}\right)$ on the $\mathrm{pH}$ of seawater. The results show a clear relationship similar to previously established empirical calibrations for planktonic foraminifera and inorganic calcite. A $-0.6 \%$ offset exists between $P$. cylindrica and A. nobilis which is systematic over the $\mathrm{pH}$ range of 7.7-8.2. To test whether the $\delta^{11} \mathrm{~B}$ of coral skeletons changes with physiological processes such as photosynthesis and respiration, corals were grown along a depth transect in their natural environment and under controlled conditions in the laboratory at varying light intensities and food supply. Although we also observe an isotopic offset between $P$. compressa and Montipora verrucosa, neither experimental treatment systematically changed the $\delta^{11} \mathrm{~B}$ of the two species. These findings are encouraging for using the boron isotope paleo-pH proxy in corals, because it appears that seawater $\mathrm{pH}$ is the dominant control on the boron isotopic composition in corals. Copyright (C) 2004 Elsevier Ltd
\end{abstract}

\section{INTRODUCTION}

Due to the tight coupling between marine carbonate chemistry and atmospheric concentrations of the greenhouse gas $\mathrm{CO}_{2}$, reconstruction of the former is one of the major goals in paleoclimatology. One of the most promising carbonate chemistry proxies for the marine environment is the boron isotopic composition $\left(\delta^{11} \mathrm{~B}\right)$ of biogenic calcium carbonates which has been established as a tracer for paleo-pH (Hemming and Hanson, 1992; Spivack et al., 1993; Sanyal et al., 1996, 2000, 2001; Palmer et al., 1998). Here we try to expand our knowledge about this proxy to another major group of marine calcifiers, scleractinian corals.

The functioning of the stable boron isotope-pH proxy has been described in detail by Hemming and Hanson (1992). Briefly, there are two dominant species of dissolved boron in the ocean, boric acid $\left.\left[\mathrm{B}(\mathrm{OH})_{3}\right)\right]$ and borate $\left[\mathrm{B}(\mathrm{OH})_{4}^{-}\right]$and their relative concentration changes with $\mathrm{pH}$. At low $\mathrm{pH}(<7)$ virtually all boron is present in the form of boric acid, whereas at high $\mathrm{pH}(>10)$ boron exists predominately in the form of borate (Fig. 1a). The stable isotope ${ }^{11} \mathrm{~B}$ is enriched in $\mathrm{B}(\mathrm{OH})_{3}$ compared to $\mathrm{B}(\mathrm{OH})_{4}^{-}$, with an effective isotopic fractionation on the order of $20 \%$ o between the two boron species (Kakihana et al., 1977). Consequently, as the relative concentration of the dissolved species changes with $\mathrm{pH}$, so does their isotopic composition (Fig. 1b).

Because diverse biogenic and inorganic marine carbonates record boron isotopic compositions that fall close to the boron isotopic composition of $\mathrm{B}(\mathrm{OH})_{4}^{-}$at modern seawater $\mathrm{pH}$, Hemming and Hanson (1992) suggested that it is the charged borate

* Author to whom correspondence should be addressed (hoenisch@1deo.columbia.edu). species that is incorporated into marine carbonates (Fig. 1b). This interpretation has subsequently been supported by a number of empirical calibration studies on planktonic foraminifera (Sanyal et al., 1996, 2001) and inorganically precipitated $\mathrm{CaCO}_{3}$ (Hemming et al., 1995; Sanyal et al., 2000) over a wide range of culture water $\mathrm{pH}$ (7.7-9.0). Using these empirical relationships to apply the boron isotope-pH proxy to the paleocean revealed a sound and promising agreement between reconstructed surface seawater $\mathrm{pH}$ (Sanyal et al., 1995) and variations in atmospheric $p \mathrm{CO}_{2}$ as measured in ice cores (Neftel et al., 1982; Fischer et al., 1999; Petit et al., 1999).

In an inorganic precipitation study Hemming et al. (1995) measured the same $\delta^{11} \mathrm{~B}$ for synthetic aragonite and calcite. Assuming that corals record seawater $\mathrm{pH}$ analogous to the previous empirical calibration studies, Hemming et al. (1998) investigated annual growth bands in a head of the zooxanthellate coral Porites lobata, recovered from Fanning Island in the western equatorial Pacific. Paired analyses of stable carbon and boron isotopes revealed a distinct seasonal variability that was interpreted to coincide with periods of changing insolation. The high density bands displayed more positive boron and carbon isotopic compositions, probably reflecting high symbiont photosynthetic activity during periods of high insolation. In support of the common carbon pool hypothesis, which postulates that carbon for both, photosynthesis and calcification, would be drawn from a single internal pool (e.g., Goreau, 1977), Hemming et al. (1998) argued that carbon fixation preferentially sequesters ${ }^{12} \mathrm{C}$, leaving the residual carbon pool enriched in ${ }^{13} \mathrm{C}$ and high in pH. Hemming et al. (1998) suggested that calcification from this pool results in the observed heavier carbon and boron isotope values. While the common carbon pool hypothesis has not been proven and other studies suggest that there may 

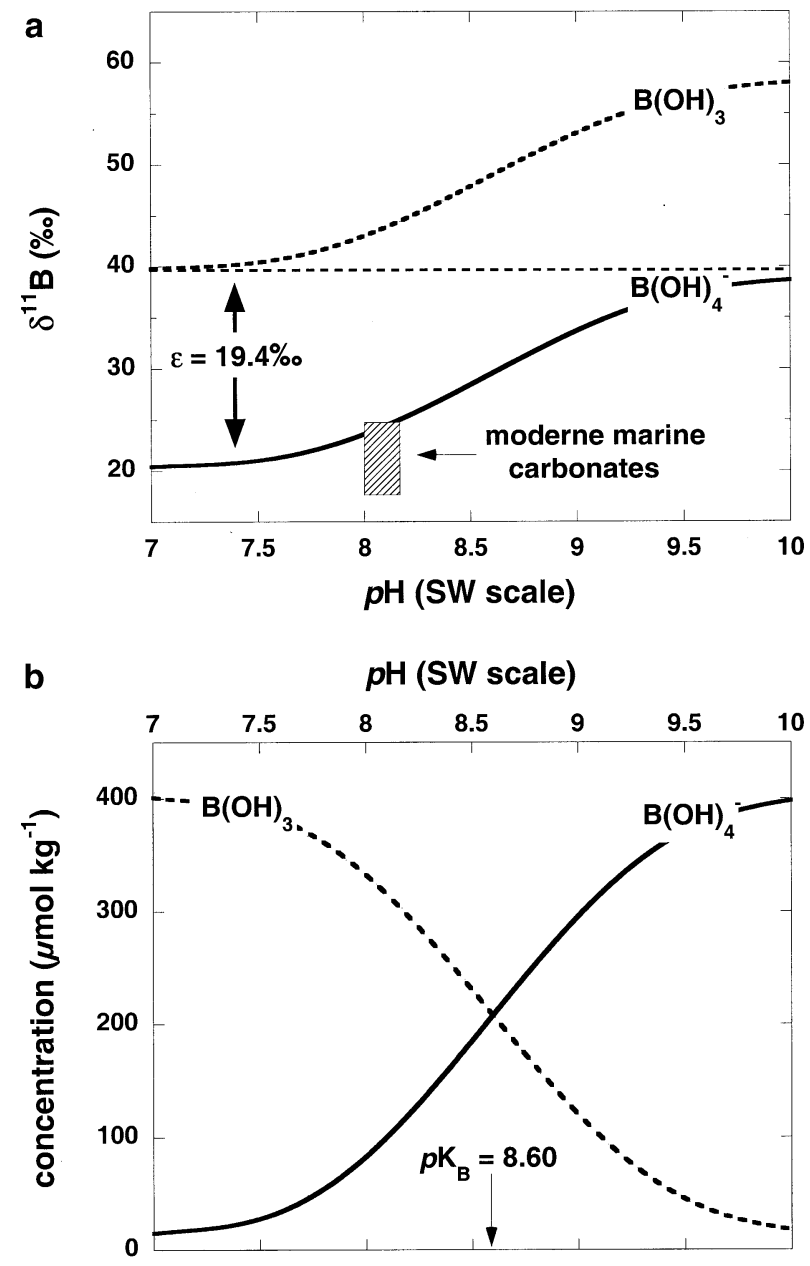

Fig. 1. Relative concentration of the two dominant boron species in seawater (a) and theoretical boron isotope partitioning (b). Calculations were done using $p \mathrm{~K}_{\mathrm{B}}=8.60$ (DOE, 1994) and Kakihana et al. (1977) fractionation factor $\varepsilon=19.4 \%$ o. $\delta^{11} \mathrm{~B}$ values of modern marine carbonates fall close to the $\mathrm{B}(\mathrm{OH})_{4}^{-}$curve (Hemming and Hanson, 1992).

be two or more carbon pools (Furla et al., 2000), carbon isotope data from coral culture experiments (Grottoli, 1999, 2002; Grottoli and Wellington, 1999) support the hypothesis. In contrast, the $\delta^{11} \mathrm{~B}$ of scleractinian corals has not yet been investigated and calibrated in detail so that a number of fundamental questions remain to be answered: Do corals follow the isotopic composition of $\mathrm{B}(\mathrm{OH})_{4}^{-}$over a wide range of seawater $\mathrm{pH}$ ? If changes in insolation affect the $\delta^{11} \mathrm{~B}$ in coral skeletons, how accurately can corals reflect seawater $\mathrm{pH}$ under the naturally varying light intensities found across the depth range of a certain species? To answer these questions, we measured the $\delta^{11} \mathrm{~B}$ of three different sets of cultured corals, grown under controlled conditions in seawater aquaria at (i) varying $P_{2}$ and thus $\mathrm{pH}$, (ii) changing light and food supply and (iii) over a depth transect within their natural environment on a reef. In comparison studies, experiments II and III have already been investigated for changes in $\delta^{13} \mathrm{C}$ (Grottoli, 1999, 2002) so that the vital effects discovered therein can be directly compared with our boron data.

\section{METHODS}

\subsection{Culturing}

\subsection{1. $\delta^{11} B-p H$ Calibration (Experiment I)}

Two species of branching, zooxanthellate scleractinian corals, Porites cylindrica and Acropora nobilis, were cultured under three different $p \mathrm{CO}_{2}$ conditions, 220, 385 and $765 \mathrm{ppm}$ in the laboratory of the Tropical Biosphere Research Centre of Ryukyus, Japan. Experiments were carried out between June 1998 and January 1999. The general culture technique followed the procedure outlined in Reynaud-Vaganay et al. (1999) and is reported in detail in Amat (2000). Briefly, for each species 20 branch tips were sampled by SCUBA divers at a depth of 2-5 $\mathrm{m}$ from two naturally grown parent colonies of the reef surrounding Sesoko Island (Japan). In the laboratory, the apical parts of the branches were cut and glued on $4 \times 4 \mathrm{~cm}$ ground glass slides. Corals were allowed to recover for a few days in flow-through seawater tanks outside of the laboratory. The glass slides were then installed in 80-L acrylate aquaria with modified seawater carbonate chemistry and after 1 to 3 weeks, corals started precipitating aragonite on the slide surfaces. Corals were allowed to calcify over a period of 40-60 d, which is the minimum time required to allow adaptation to the new environment and obtain sufficient skeletal material for subsequent analysis. Upon completion of the culture period, the $\mathrm{CaCO}_{3}$ precipitated during the experiment was removed from the slide with a scalpel, bleached, dried and archived for later analysis.

Throughout the culture period seawater with a constant temperature of $27 \pm 0.4^{\circ} \mathrm{C}$ was pumped directly from the reef site into the aquaria. Corals were exposed to a 14:10-h light:dark cycle and irradiances were $300 \pm 15 \mu \mathrm{mol}$ photons $\mathrm{m}^{-2}$ for $\mathrm{s}^{-1}$ for A. nobilis and $330 \pm 20 \mu \mathrm{mol}$ photons $\mathrm{m}^{-2} \mathrm{~s}^{-1}$ for $P$. cylindrica. $p \mathrm{CO}_{2}$ was modified by bubbling air with (a) no, (b) normal atmospheric and (c) high $\mathrm{CO}_{2}$ concentration into the culture seawater. Air and water supply to the aquarium were regulated in order to adjust and maintain the target $\mathrm{CO}_{2}$ concentration. Conditions (b) and (c) were open to the atmosphere and only the aquarium for condition (a) was covered to prevent $\mathrm{CO}_{2}$ invasion from the atmosphere. Continuous gas flow allowed the constancy of the normal and high $p \mathrm{CO}_{2}$ conditions over the course of the experiment. Temperature, light, and carbonate chemistry in the seawater tanks were constantly monitored and remained unchanged throughout the culture period. Direct $\mathrm{pH}$ measurements were not well calibrated, however, using coulometrically measured concentrations of dissolved inorganic carbon (DIC) and potentiometrically titrated alkalinities (Table 1), $\mathrm{pH}$ of the culture seawater was calculated according to the CO2SYS program by Lewis and Wallace (1998), using $K_{1}$ and $K_{2}$ as determined by Mehrbach et al. (1973) (values refit by Dickson and Millero, 1987 for the seawater scale) and $\mathrm{K}_{\mathrm{SO} 4}$ as determined by Dickson (1990). Analytical uncertainties for DIC and alkalinity analyses are \pm 2 $\mu \mathrm{mol} \mathrm{kg}{ }^{-1}$ and $\pm 4 \mu \mathrm{mol} \mathrm{kg}{ }^{-1}$, respectively. Repeated carbonate chemistry analyses of the culture water revealed a much larger variability (Table 1) which translates into an average uncertainty of the calculated $\mathrm{pH}$ values of $\pm 0.05 \mathrm{pH}$ units. 
Table 1. Boron isotopic composition and concentration of Acropora nobilis and Porites cylindrica, grown under various pH. ${ }^{\mathrm{a}}$

\begin{tabular}{|c|c|c|c|c|c|c|}
\hline \multirow[b]{2}{*}{$\begin{array}{c}\text { Alkalinity } \\
\left(\mu \mathrm{mol} \mathrm{kg}{ }^{-1}\right)\end{array}$} & \multirow[b]{2}{*}{$\begin{array}{c}\text { DIC } \\
\left(\mu \mathrm{mol} \mathrm{kg}{ }^{-1}\right)\end{array}$} & \multirow[b]{2}{*}{$\begin{array}{c}\mathrm{pH} \\
\text { (SW scale) }\end{array}$} & \multicolumn{2}{|c|}{ Acropora nobilis } & \multicolumn{2}{|c|}{ Porites cylindrica } \\
\hline & & & $\begin{array}{l}\delta^{11} \mathrm{~B} \\
(\% o)\end{array}$ & $\begin{array}{c}\text { Boron }_{\text {coral }} \\
(\mathrm{ppm})\end{array}$ & $\begin{array}{l}\delta^{11} \mathrm{~B} \\
(\% o)\end{array}$ & $\begin{array}{c}\text { Boron }_{\text {coral }} \\
(\mathrm{ppm})\end{array}$ \\
\hline $2167 \pm 20$ & $2022 \pm 30$ & 7.71 & 21.1 & 63.0 & 21.7 & 55.6 \\
\hline $2118 \pm 24$ & $1858 \pm 26$ & 7.96 & 22.9 & 57.9 & 23.5 & 55.5 \\
\hline $2108 \pm 10$ & $1732 \pm 35$ & 8.16 & 24.5 & 54.3 & 24.9 & 56.0 \\
\hline
\end{tabular}

${ }^{\mathrm{a}} \mathrm{pH}$ values were calculated based on measured alkalinity and DIC values. Analytical uncertainty, as determined by repeat analyses of open ocean seawater, is $2 \sigma$ uncertainty $= \pm 0.31 \%$ o. $\delta^{11} \mathrm{~B}(\%)=\left(\mathrm{R}_{\mathrm{s}} / \mathrm{R}_{\mathrm{std}}-1\right) \times 1000, \mathrm{R}_{\mathrm{s}}={ }^{11} \mathrm{~B} /{ }^{10} \mathrm{~B}$ of sample, $\mathrm{R}_{\text {std }}={ }^{11} \mathrm{~B} /{ }^{10} \mathrm{~B}$ of $\mathrm{NBS} 951$ boric acid standard.

\subsubsection{Light and Feeding Experiments (Experiment II)}

This experiment was conducted at the Hawaii Institute of Marine Biology on Coconut Island (Kaneohe Bay), Hawaii, from August to October 1996 for a total duration of 57 days. The experimental setup is described in detail in Grottoli (2002). Briefly, fragments of the symbiont-bearing, branching coral Porites compressa were grown in outdoor flow-through tanks under natural sunlight at 540, 810, 1080, and $1210 \mu \mathrm{mol}$ photons $\mathrm{m}^{-2} \mathrm{~s}^{-1}$. Within each light treatment, corals were fed either zero, low, medium, or high concentrations of brine shrimp (Artemia sp.).

Approximately $4 \mathrm{~cm}$ tall coral fragments were collected from 10 individual colonies of $P$. compressa at a depth of $2.0 \mathrm{~m}$ on the reef. Fragments were fixed to a $2 \times 4 \mathrm{~cm}$ ceramic tile and allowed to acclimate in the aquaria for $5 \mathrm{~d}$ before the start of the actual experiment. Before they were placed in their respective treatments, coral fragments were stained with Alizarin red to mark the beginning of the experiment. Placing neutral density mesh screens across parts of the aquaria created the four light conditions. The second-highest light intensity, $1080 \mu \mathrm{mol}$ photons $\mathrm{m}^{-2} \mathrm{~s}^{-1}$, is equivalent to the light intensity measured at the $2 \mathrm{~m}$ coral collection depth. Each evening, corals were placed in feeding chambers and fed 2-d-old brine shrimp nauplii for a duration of $2 \mathrm{~h}$. Brine shrimp concentrations in the 13.42-L feeding chambers were $0,0.73,3.42$ and 11.12 brine shrimp/ml in the zero, low, medium and high food treatments, respectively. Upon completion of the experiments, coral fragments were stained with Alizarin Red again and left in the tanks for further deposition of skeleton beyond the stainline.

Coral fragments were cleaned with high-pressure tap water, ultrasonicated in distilled water and then dried in an oven at $60^{\circ} \mathrm{C}$. Of the 10 replicate samples available for each treatment, one to three of each group were selected for boron isotope analysis. Skeletal material was extracted by drilling a homogenized bulk sample between the two stain lines of each coral fragment, using a 1-mm diamond-tipped dental bit. The skeleton material was consistently sampled along the major growth axis, approximately $1-2 \mathrm{~mm}$ below the branch tip.

\subsubsection{Depth Transect (Experiment III)}

To assess the natural variation in $\delta^{11} \mathrm{~B}$ across depth and between species, coral fragments of the two species Porites compressa and Montipora verrucosa were collected at 1.7, 5.0 and $8.3 \mathrm{~m}$ depth from The Point Reef, Coconut Island (Kaneohe Bay), Hawaii, in August 1996, the beginning of the dry season at this location. A detailed description of sampling and growth procedure, reef environment and the species investigated can be found in Grottoli (1999). The fragments were stained with Alizarin red and cemented back to their respective collection site. All coral fragments were restained in November 1996 and eventually collected in March 1997. Upon termination of the experiment, corals were cleaned and prepared for further analysis as already outlined for Experiment 11.

\subsection{Boron Isotope Analysis}

For boron isotope analysis approximately $3 \mathrm{mg}$ coral powder was bleached with 4-6\% sodium hypochlorite to remove organic matter and then rinsed, ultrasonicated and centrifuged with distilled water to remove soluble salt and any adsorbed boron (B). The supernatant was then siphoned off and the entire process (rinsing, ultrasonication, centrifugation, water removal) was repeated 10 times. Analyses were done on an NBS design, $15 \mathrm{~cm}$ radius of curvature thermal ionization mass spectrometer at the State University of New York at Stony Brook (Hemming and Hanson, 1994). Aliquots of each sample solution were run at least three times to eliminate analytical artifacts such as excessive fractionation and/or isobaric interference on mass 42 with organic matter contamination $\left({ }^{12} \mathrm{C}^{14} \mathrm{~N}^{16} \mathrm{O}\right.$-ions). Organic matter contamination was monitored on mass $26\left({ }^{12} \mathrm{C}^{14} \mathrm{~N}\right.$-ions $)$. No mass 26 signal was detected during this study. Runs were considered acceptable when fractionation was less than $1 \%$ (i.e., $<0.004$ in the $43 / 42$ ratio) over a minimum acquisition time of 20 minutes (i.e., 60 isotope ratios). Unlike foraminifera samples, coral samples fractionate very rarely (less than $10 \%$ of all analyses in this study). Data are recorded in delta notation relative to NBS 951 boric acid standard. Repeated analyses (n $=39$ ) of natural seawater used as a laboratory standard resulted in an average value of $39.7 \pm 0.31 \%$ o (uncertainty calculated as $2 \sigma / \sqrt{ } 3$ to account for the fact that coral solutions were measured at least three times). The seawater value is in good agreement with previous studies (Hemming and Hanson, 1992; Spivack et al., 1993; Sanyal et al., 1996). Repeated analyses of the same coral sample solutions resulted in uncertainties that were often better than $\pm 0.3 \%$ and seldom worse than that. Samples and standards were measured at a filament temperature of $970 \pm 10^{\circ} \mathrm{C}$.

\subsection{Boron Speciation and Isotope Partitioning}

The work of Hemming and Hanson (1992) catalyzed a number of studies that corroborated the validity of $\delta^{11} \mathrm{~B}$ in biogenic carbonates as a proxy for past seawater $\mathrm{pH}$. However, 
confusion exists about the constants being used to calculate the $\mathrm{pH}$ dependent speciation of $\mathrm{B}$ and the isotope partitioning between the two dominant $\mathrm{B}$ species. The fractionation between $\mathrm{B}(\mathrm{OH})_{4}^{-}$and $\mathrm{B}(\mathrm{OH})_{3}$ has not yet been determined experimentally and the fact that $\delta^{11} \mathrm{~B}$ of a variety of modern marine carbonates fall below the theoretical $\mathrm{B}(\mathrm{OH})_{4}^{-}$curve (Fig. 1, Hemming and Hanson, 1992) has caused speculation about the validity of Kakihana et al.'s (1977) theoretically calculated fractionation $\varepsilon=19.4 \%$ (at $25^{\circ} \mathrm{C}$ and $P=1 \mathrm{~atm}$ ). However, if $\varepsilon$ were $24 \%$ as suggested by the data of Palmer et al. (1987) (see also Zeebe and Wolf-Gladrow, 2001), the slope of the $\mathrm{B}(\mathrm{OH})_{4}^{-}$and the $\mathrm{B}(\mathrm{OH})_{3}$ curves would be so much steeper that all existing calibration curves would not be parallel to the $\mathrm{B}(\mathrm{OH})_{4}^{-}$curve but would show varying offsets. This could be corrected for by increasing $\mathrm{pK}_{\mathrm{B}}$ from 8.60 (at $25^{\circ} \mathrm{C}$ and $\mathrm{S}=35$, DOE, 1994) to $\sim 8.9$. The empirical and the theoretical curves would then be parallel again. However, $\mathrm{pK}_{\mathrm{B}}$ in seawater was determined experimentally and it is therefore unlikely to be very different from 8.60 . Therefore, $\varepsilon$ can not be too much different from Kakihana et al.'s (1977) value. In fact, the existing empirical curves provide an indirect confirmation of Kakihana et al.'s (1977) $\varepsilon$. Following this line of argument, we use $\varepsilon=19.4 \%$ and $\mathrm{pK}_{\mathrm{B}}=8.60$ for presentation of our data. A more detailed discussion for the choice of constants can be found in Zeebe and Wolf-Gladrow (2001).

\subsection{Statistical Analyses}

The effects of light and food on $\delta^{11} \mathrm{~B}$ from experiment II were statistically evaluated using a two-way, Model III analysis of variance (ANOVA). A posteriori Tukey tests were used to determine which light and food treatments significantly differed from each other. The effect of depth and species on $\delta^{11} \mathrm{~B}$ from experiment III were also statistically evaluated using a two-way, Model III ANOVA with a posteriori Tukey tests where appropriate. Correlation analyses between $\delta^{13} \mathrm{C}$ and $\delta^{11} \mathrm{~B}$ were also performed. In all cases, the statistical computations were done using SAS Statistical software (SAS 8, SAS Institute, Cary, NC). Null hypotheses were rejected when the probability level was less than 0.05 .

\section{RESULTS}

\subsection{Empirical Calibrations (Experiment I)}

Figure 2 clearly shows the $\mathrm{pH}$ dependence of the boron isotopic composition of the two coral species A. nobilis and $P$. cylindrica (see also Table 1 for the compiled data). The $\delta^{11} \mathrm{~B}$ of these cultured corals systematically increases with $\mathrm{pH}$. The $\mathrm{pH}$ trend is similar to that of the theoretical borate curve (Kakihana et al., 1977) and the empirical calibrations previously established for planktonic foraminifera (Sanyal et al., 1996, 2001). Also shown in Figure 2 are recent $\delta^{11} \mathrm{~B}$ data for Acropora sp. which was grown at two different $\mathrm{pH}\left(p \mathrm{CO}_{2}\right)$ conditions in a similar laboratory study (Reynaud et al., in press). Their data closely match ours and corroborate the robustness of our calibrations.

\subsection{Light and Feeding (Experiment II)}

Results from the tank experiments conducted on Hawaii are shown in Figure 3 and Table 2. Some variability exists among a
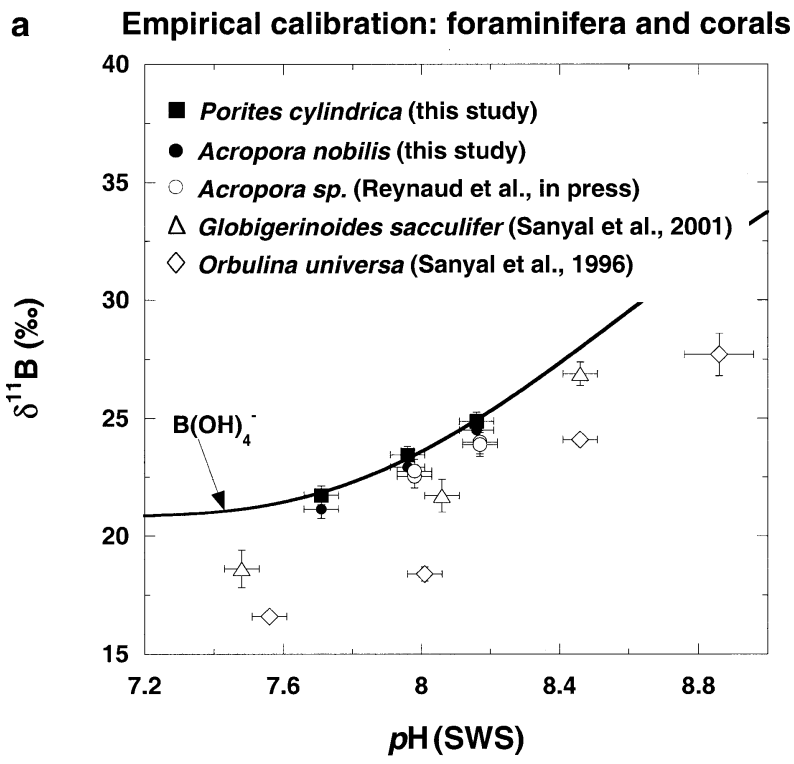

b

b Empirical calibration: corals

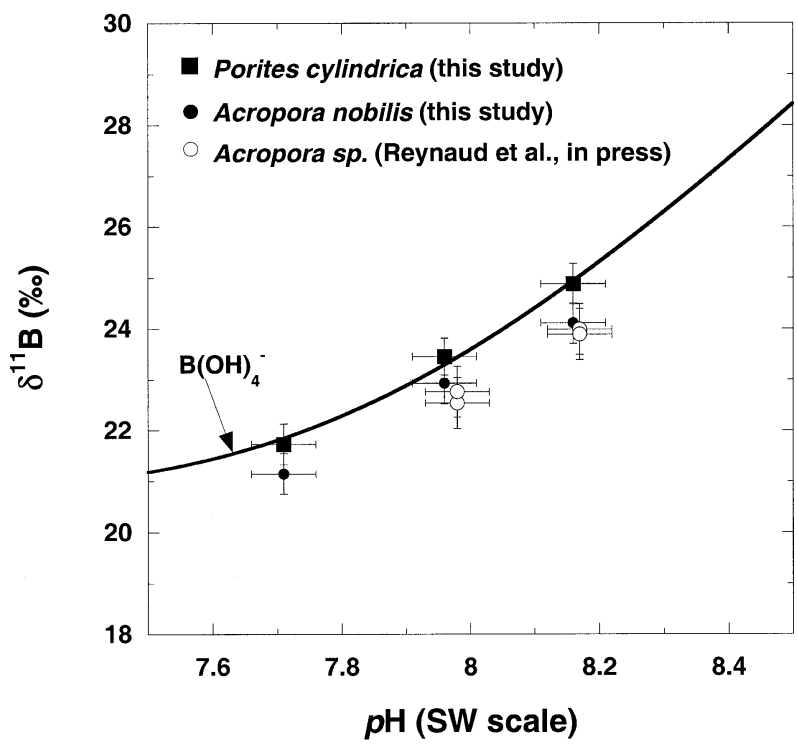

Fig. 2. (a) Empirical relationship between $\delta^{11} \mathrm{~B}$ and seawater $\mathrm{pH}$ for the two symbiont-bearing foraminifera Globigerinoides sacculifer (open triangles) (Sanyal et al., 2001) and Orbulina universa (open diamonds) (Sanyal et al., 1996), as well as zooxanthellate corals' $P$. cylindrica (squares) and A. nobilis (closed circles). Sanyal et al. (1996; 2001) data were shifted by $-0.14 \mathrm{pH}$ units to account for the difference between NBS and seawater $\mathrm{pH}$ scale. Empirical calibrations of cultured corals ( $\pm 2 \sigma$ analytical uncertainty) are enlarged in (b). The Porites cylindrica skeleton is the only known biogenic carbonate whose $\delta^{11} \mathrm{~B}$ falls directly onto Kakihana et al. (1977) theoretical $\mathrm{B}(\mathrm{OH})_{4}^{-}$curve. Acropora nobilis closely follows the shape of the theoretical curve but is offset by $-0.6 \%$ o. Our data closely agree with $\delta^{11} \mathrm{~B}$-calibration data for Acropora sp. (open circles) by Reynaud et al. (in press).

samples but neither light (Fig. 3a) nor food supply (Fig. 3b) lead to a systematic change in $\delta^{11} \mathrm{~B}$. The only trend in the data occurs at the highest light intensity where $\delta^{11} \mathrm{~B}$ appears to increase with food availability (Table 2). However, statistical evaluation (Table 4) confirms that skeletal $\delta^{11} \mathrm{~B}$ is overall not 


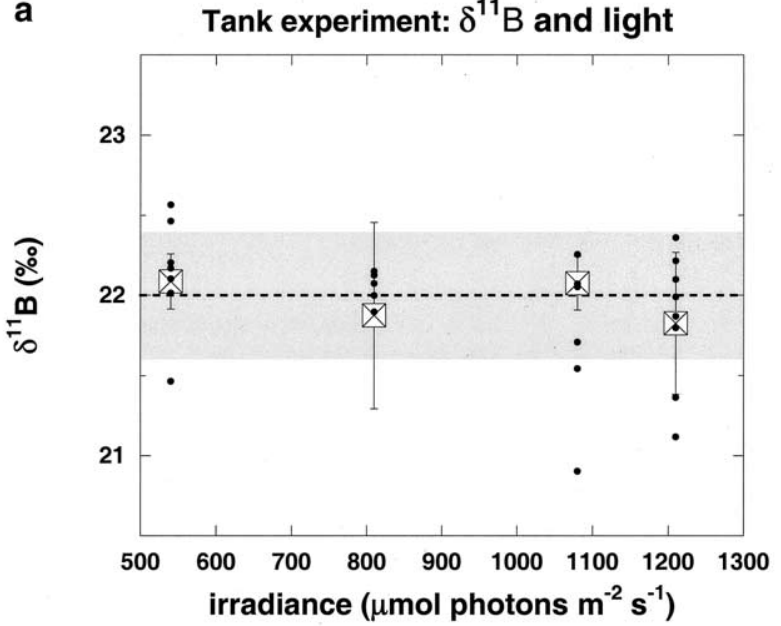

b

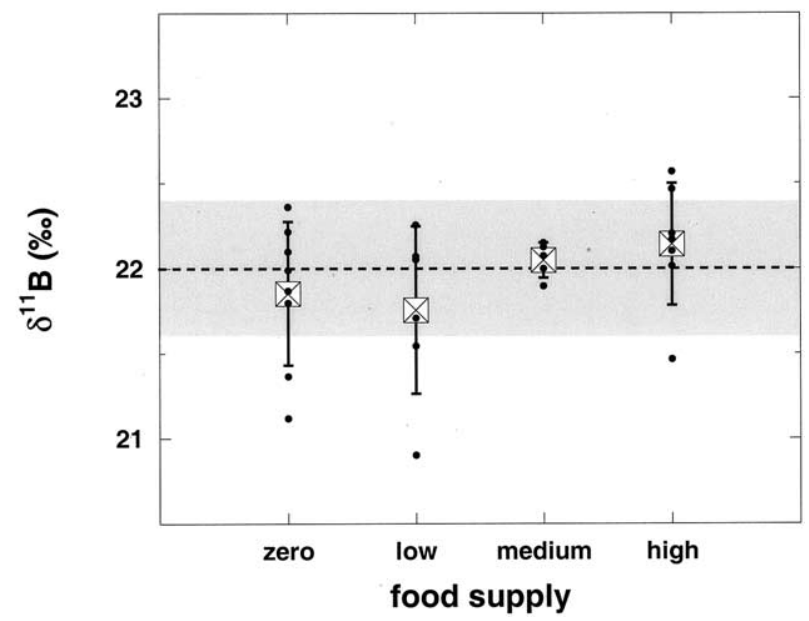

Fig. 3. $\delta^{11} \mathrm{~B}$ of $P$. compressa fragments, grown in seawater aquaria at (a), various light intensities $\left(540-1210 \mu \mathrm{mol}\right.$ photons $\left.\mathrm{m}^{-2} \mathrm{~s}^{-1}\right)$, and (b), feeding conditions. Squares and error bars indicate mean values $\pm 1 \mathrm{sd}$ of all measured samples. Analytical $2 \sigma$ uncertainty of individual fragments (solid dots) is $\pm 0.3 \%$ (not indicated in figures). Neither light nor nitrogen fertilization (i.e. food supply) systematically change the $\delta^{11} \mathrm{~B}$ values, hence the $\mathrm{pH}$ record of the corals. Only 7 out of 28 samples randomly deviate by more than $1 \mathrm{sd}( \pm 0.4 \%$, gray bars) from the overall average of $22.0 \%$ (dashed lines) and statistical analysis (2-way Model III ANOVA) confirms the lack of light (probability level $p=0.79)$, feeding $(p=0.79)$ or interaction effects $(p=0.79)$. Given light intensities are assumed to be above the onset of light saturation for the symbiont host association. See text for details.

affected by light intensity ( $p=0.79$ ) or food availability ( $p=$ $0.79)$. Similarly, interaction effects between food, light and $\delta^{11} \mathrm{~B}$ were not significant $(p=0.79)$.

Because most of the samples used for boron isotope analysis originate from the same coral head (\#10, Table 2), samples from different mother colonies (\#1-9) were randomly selected to test whether the initially chosen coral may have been an especially insensitive individual. Most replicate samples from different coral heads gave similar $\delta^{11} \mathrm{~B}$ values. Twenty-one out of 28 samples are within 1 standard deviation $( \pm 0.4 \%$ ) of the overall average of $22.0 \%$ o. Few outliers occur randomly among different experimental treatments (Fig. 3) and cannot be ex- plained by genotypic variability between individual coral colonies (Table 2).

\subsection{Depth Transect (Experiment III)}

Similar to the offset between $P$. cylindrica and A. nobilis (Fig. 2) there is a systematic offset between $P$. compressa and $M$. verrucosa that is marginally significant ( $p=0.0718$, Fig. 4, Table 3, Table 4). Overall our data show some variation with depth but the two coral species do not display a systematic trend towards lighter $\delta^{11} \mathrm{~B}$. Statistical evaluation with few data pointa is not very reliable but indicates that the depth effect is not significant $(p=0.326)$.

\section{DISCUSSION}

\subsection{Which Fluid pH Is Recorded?}

Although our calibrations are similar in shape to the theoretical borate curve, only $P$. cylindrica falls onto the curve and A. nobilis is consistently offset by $-0.6 \%$ (Fig. 2b). Such a negative deviation from the theoretical borate curve has been observed in all previous calibration studies and cannot be explained by known vital effects. Similarly, relative differences

Table 2. Boron isotopic composition and concentration of Porites compressa, grown under different light intensities and varying food supply. ${ }^{\mathrm{a}}$

\begin{tabular}{|c|c|c|c|c|}
\hline $\begin{array}{c}\text { Light }(\mu \mathrm{mol} \\
\left.\text { photons } \mathrm{m}^{-2} \mathrm{~s}^{-1}\right)\end{array}$ & Food & Specimen & $\begin{array}{l}\delta^{11} \mathrm{~B} \\
(\% o)\end{array}$ & $\begin{array}{l}\text { Boron }_{\text {coral }} \\
\quad(\mathrm{ppm})\end{array}$ \\
\hline 1210 & zero & 10 & 21.4 & 46.3 \\
\hline 1210 & zero & 6 & 21.2 & 40.4 \\
\hline 1210 & zero & 2 & 22.1 & 44.8 \\
\hline 1210 & low & 10 & 21.7 & 47.2 \\
\hline 1210 & low & 4 & 21.6 & 47.1 \\
\hline 1210 & medium & 10 & 22.0 & 47.9 \\
\hline 1210 & medium & 4 & 22.1 & 44.3 \\
\hline 1210 & high & 10 & 22.2 & 44.8 \\
\hline 1210 & high & 2 & 22.1 & 39.2 \\
\hline 1210 & high & 1 & 22.6 & 46.3 \\
\hline 1080 & zero & 10 & 21.8 & N/A \\
\hline 1080 & zero & 2 & 22.1 & 41.8 \\
\hline 1080 & low & 10 & 22.3 & 46.3 \\
\hline 1080 & medium & 10 & 22.1 & N/A \\
\hline 1080 & high & 7 & 22.1 & 48.6 \\
\hline 810 & zero & 10 & 22.2 & 46.1 \\
\hline 810 & low & 10 & 21.0 & N/A \\
\hline 810 & low & 2 & 22.1 & 40.2 \\
\hline 810 & medium & 10 & 22.2 & N/A \\
\hline 810 & high & 1 & 22.5 & 41.4 \\
\hline 810 & high & 9 & 21.5 & 44.1 \\
\hline 540 & zero & 10 & 21.9 & N/A \\
\hline 540 & zero & 1 & 22.4 & 45.8 \\
\hline 540 & low & 10 & 22.1 & 46.1 \\
\hline 540 & medium & 10 & 22.0 & N/A \\
\hline 540 & high & 8 & 22.2 & 45.0 \\
\hline 540 & high & 4 & 21.9 & 44.5 \\
\hline reef control & & & 21.6 & 42.6 \\
\hline average & & & 22.0 & 44.6 \\
\hline
\end{tabular}

${ }^{a}$ Colony number indicates the coral head from which individual branches were broken and incubated under different experimental conditions. Most samples are from coral head 10, others were selected randomly to test genotypic variability. N/A indicates samples where boron concentrations were not measured. See Table 1 for explanation of boron data. 


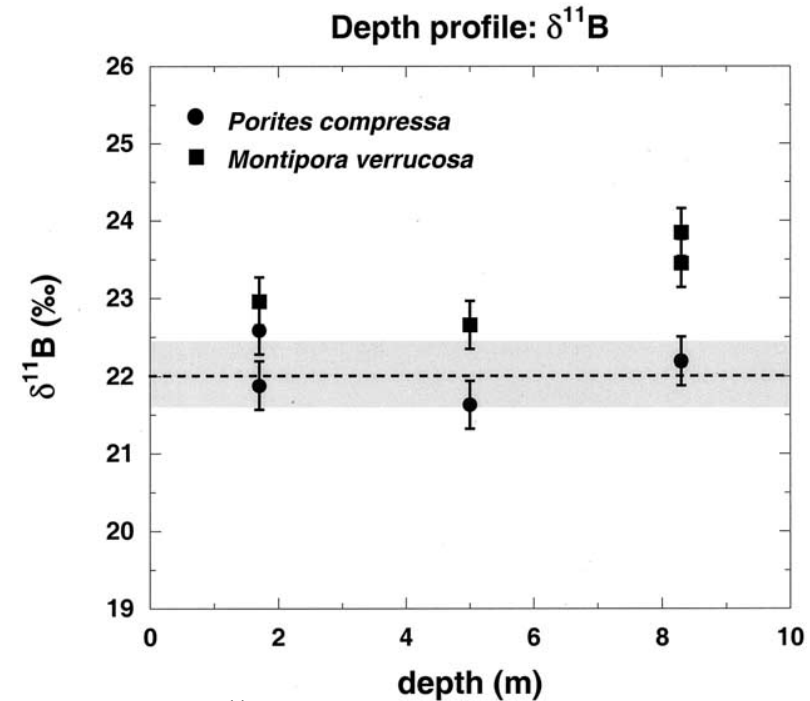

Fig. 4. Mean $\delta^{11} \mathrm{~B}( \pm 2 \sigma$ analytical uncertainty) of individual $P$. compressa (circles) and $M$. verrucosa (squares) fragments grown across a depth transect with light intensities between $>500 \mu \mathrm{mol}$ photons $\mathrm{m}^{-2} \mathrm{~s}^{-1}$ at $1.7 \mathrm{~m}$ depth and $30-200 \mu$ mol photons $\mathrm{m}^{-2} \mathrm{~s}^{-1}$ at $8.3 \mathrm{~m}$ depth. A posteriori Tukey tests revealed that $\delta^{11} \mathrm{~B}$ does not differ between depths $(p=0.32)$. Dashed line and gray bar indicate the average $\delta^{11} \mathrm{~B}_{P \text {. compressa }} \pm 1 \mathrm{sd}$ as found in the light and food experiments (Fig. 3). Although light intensities were much higher in the tank experiments, $\delta^{11} \mathrm{~B}$ data are the same across the depth profile. There is a consistent offset in $\delta^{11} \mathrm{~B}$ between $M$. verrucosa and $P$. compressa on the order of $+1.1 \%$ o $(p=0.07)$.

between the two foraminifera Orbulina universa and Globigerinoides sacculifer (Fig. 2a) could not be entirely explained by physiological processes (Zeebe et al., 2003).

Unlike foraminifera, the coral skeleton is separated by three tissue layers from the seawater in which the coral is bathed. McConnaughey and Whelan (1997) suggested a "trans" calcification mechanism for corals and most other biologic calcifiers, where active counterport of $\mathrm{Ca}^{2+}$ and $2 \mathrm{H}^{+}$by a membrane bound $\mathrm{Ca}^{2+}$-ATPase establishes a $\mathrm{pH}$ gradient across the calicoblastic tissue layer. $\mathrm{CO}_{2}$ crosses the lipid tissue layer by diffusion to the calcification site where it is converted to $\mathrm{HCO}_{3}^{-}$ and $\mathrm{CO}_{3}^{2-}$ due to the high $\mathrm{pH}$. Elevated $\left[\mathrm{Ca}^{2+}\right]$ and $\left[\mathrm{CO}_{3}^{2-}\right]$ adjacent to the skeleton then promote calcification and protons transported from the calcification site increase $\left[\mathrm{CO}_{2}\right]$ and $\left[\mathrm{HCO}_{3}\right]$ for symbiont photosynthesis. Although the concurrent enhancement of calcification and photosynthesis through this mechanism is not consistently supported by the literature (e.g.,
Marshall, 1996; Gattuso et al., 2000), Al-Horani et al.'s (2003) data support the $\mathrm{Ca}^{2+} / 2 \mathrm{H}^{+}$counterport. In the light, the zooxanthellate coral Galaxea fascicularis shows elevated $\left[\mathrm{Ca}^{2+}\right]$ and $\mathrm{pH}$ at the polyp surface and in the calcifying fluid under the subcalicoblastic layer relative to ambient seawater $\mathrm{pH}$ and the coelenteron (Al-Horani et al., 2003). Because of the separating tissue layer, the subcalicoblastic fluid must be the site of relevance for the $\mathrm{pH}$ recorded in coral $\delta^{11} \mathrm{~B}$. The isotopic equilibration between $\mathrm{B}(\mathrm{OH})_{3}$ and $\mathrm{B}(\mathrm{OH})_{4}^{-}$is virtually instantaneous $(\sim 125 \mu \mathrm{s})$ (Zeebe et al., 2001), so that the $\mathrm{pH}$ recorded in coral $\delta^{11} \mathrm{~B}$ must be higher than ambient seawater $\mathrm{pH}$. This assumption is also supported by Hemming et al. (1995) who found that $\delta^{11} \mathrm{~B}$ of inorganically precipitated aragonite and calcite are the same. Because $\delta^{11} \mathrm{~B}$ of aragonite precipitated by corals is more positive relative to foraminifera (Fig. 2a), coral $\delta^{11} \mathrm{~B}$ could therefore be indicative of a relatively higher integrated $\mathrm{pH}$ at the site of calcification. Plotting the measured $\delta^{11} \mathrm{~B}$ values versus the experimental seawater $\mathrm{pH}$ (Fig. 2) is therefore not exactly correct. However, estimating the integrated $\mathrm{pH}$ at the calcification site is difficult because little is known about diurnal physiological variations and the integrated $\mathrm{pH}$ may therefore not be equal to the average between light and dark $\mathrm{pH}$ as measured by Al-Horani et al. (2003). The situation is aggravated by the possibility that the isotopic signature of the $B$ species in the coralline calcifying fluid may be different from the respective seawater value. The question is how B reaches the site of calcification. Are both species transported to the calcification site in their $\mathrm{pH}$-dependent ratio? If $\mathrm{B}(\mathrm{OH})_{3}$ as the uncharged species were to pass the lipid tissue layers preferentially, the initial isotopic signature of all B present at the site of calcification may be higher than $\delta^{11} \mathrm{~B}$ of ambient seawater. Because the alkaline $\mathrm{pH}$ at the calcification site will convert $\mathrm{B}(\mathrm{OH})_{3}$ to $\mathrm{B}(\mathrm{OH})_{4}^{-}$and the isotopic equilibration will be instantaneous, the $\mathrm{B}(\mathrm{OH})_{4}^{-}$incorporated into the coral skeleton will be offset to the theoretical value at that $\mathrm{pH}$. This type of uncertainty is the reason why establishing empirical calibrations is such an important task. Comparison of $\delta^{11} \mathrm{~B}$ values between coral (and/or foraminifera) species that were grown at the same ambient seawater $\mathrm{pH}$ may not tell us the species difference in $\mathrm{pH}$ at their respective calcification sites. Microsensor analyses on living corals and foraminifera will provide a much better means for that purpose. However, the calibrations presented herein were established in order to trace past seawater $\mathrm{pH}$. The observed correlation between $\delta^{11} \mathrm{~B}$ and $\mathrm{pH}$ (Fig. 2b) suggests that alkalization of the calcification site is fairly constant. If the offset between $\mathrm{pH}$ at the site of

Table 3. Boron isotopic composition and concentration of Porites compressa and Montipora verrucosa, grown across a depth transect in Kaneohe Bay, Hawaii. ${ }^{a}$

\begin{tabular}{|c|c|c|c|c|c|c|}
\hline \multicolumn{4}{|c|}{ Porites compressa } & \multicolumn{3}{|c|}{ Montipora verrucosa } \\
\hline Depth $(\mathrm{m})$ & Fragment No. & $\delta^{11} \mathrm{~B}(\% \circ)$ & Boron $_{\text {coral }}(\mathrm{ppm})$ & Fragment No. & $\delta^{11} \mathrm{~B}(\% o)$ & Boron $_{\text {coral }}(\mathrm{ppm})$ \\
\hline 1.7 & 56 & 22.6 & N/A & 51 & 23.0 & N/A \\
\hline 1.7 & 51 & 21.9 & 42.2 & & & \\
\hline 5 & 155 & 21.6 & N/A & 151 & 22.7 & N/A \\
\hline 8.3 & 255 & 22.2 & N/A & 253 & 23.9 & N/A \\
\hline 8.3 & & & & 255 & 23.5 & 52.3 \\
\hline
\end{tabular}

${ }^{a}$ See Table 1 for explanation of boron data. N/A indicates samples where boron concentrations were not measured. 
Table 4. Two-way model III ANOVA of light, feeding, depth and species effects on skeletal $\delta^{11} \mathrm{~B}$ in the coral Porites compressa (Experiments II and III) and Montipora verrucosa (Experiment III). ${ }^{a}$

\begin{tabular}{clrrrr}
\hline \multirow{2}{*}{ Experiment } & \multicolumn{5}{c}{$\delta^{11} \mathrm{~B}$} \\
\cline { 3 - 6 } & \multicolumn{1}{c}{ Source } & DF & \multicolumn{1}{c}{ SS } & \multicolumn{1}{c}{ F } & Prob $>$ F \\
\hline \multirow{2}{*}{ II } & Model & 15 & 1.744 & 0.62 & 0.81 \\
& Light & 3 & 0.194 & 0.34 & 0.794 \\
& Feeding & 3 & 0.195 & 0.34 & 0.794 \\
\multirow{5}{*}{ III } & Light*Feeding & 9 & 0.986 & 0.58 & 0.787 \\
& Model & 3 & 3.693 & 4.45 & 0.193 \\
& Depth & 2 & 0.687 & 2.07 & 0.326 \\
& Species & 1 & 2.067 & 12.45 & 0.072 \\
& Depth*Species & 2 & 0.181 & 0.55 & 0.647 \\
\hline
\end{tabular}

\footnotetext{
a Overall experiment II model $\mathrm{r}^{2}=0.46, \mathrm{n}=27$; experiment III model $\mathrm{r}^{2}=0.92, \mathrm{n}=8 . \mathrm{F}=\mathrm{F}$ ratio; $\mathrm{DF}=$ degrees of freedom; $\mathrm{SS}=$ sum of squares.
}

calcification and ambient seawater $\mathrm{pH}$ were constant under various conditions, the calibrations shown in Figure $2 \mathrm{~b}$ would serve as accurate means to translate recorded $\delta^{11} \mathrm{~B}$ values of fossil corals into paleo-seawater $\mathrm{pH}$. If the (physiological) processes that establish the $\mathrm{pH}$ offset between the site of calcification and ambient seawater were not constant under variable conditions, $\mathrm{pH}$-reconstructions from coral skeletons would be vulnerable to misinterpretations of the paleoceanic environment. Investigation of this possibility is the subject of the second part of our study.

\subsection{Physiological Processes and Their Potential Influence on $\delta^{11} B$ and $\delta^{13} C$}

Processes that are most likely to modify carbonate chemistry (and thus $\delta^{11} \mathrm{~B}$ ) in the microenvironment of a living organism are photosynthesis, respiration and calcification (WolfGladrow et al., 1999). Whereas respiration and calcification release $\mathrm{CO}_{2}$ and thereby decrease $\mathrm{pH}$ in the microenvironment of a calcifying organism, in the light the $\mathrm{pH}$ at the site of calcification in symbiont-bearing foraminifera (Jørgensen et al., 1985; Rink et al., 1998) and corals (Kühl et al., 1995; AlHorani et al., 2003) is significantly higher than ambient seawater $\mathrm{pH}$. In foraminifera, the elevated microenvironment $\mathrm{pH}$ can be explained by photosynthetic removal of $\mathrm{CO}_{2}$ (WolfGladrow et al., 1999). A corresponding change in $\delta^{11} \mathrm{~B}$ has been observed experimentally (Hönisch et al., 2003) and modeled (Zeebe et al., 2003) for the symbiont bearing foraminifera $O$. universa under varying light conditions.

For the very same corals investigated in this study, Grottoli (2002) found increasing $\delta^{13} \mathrm{C}$ values with increasing light and food supply (Figs. 5a and b) and decreasing $\delta^{13} \mathrm{C}$ with depth on the reef (Grottoli, 1999) (Fig. 5c). These findings agree well with the hypothesis that symbionts preferentially sequester isotopically light ${ }^{12} \mathrm{C}$ during photosynthesis and leave the isotopically heavy carbon for skeletogenesis. As one controlling factor of photosynthetic rate is light intensity, $\delta^{13} \mathrm{C}$ of the coral skeleton must change with depth. The decrease in coral $\delta^{13} \mathrm{C}$ between 1080 and $1210 \mu \mathrm{mol}$ photons $\mathrm{m}^{-2} \mathrm{~s}^{-1}$ in the tank experiment (Fig. 5a) was proposed to be due to a photoinhibition effect (Grottoli, 2002).

Since organic matter is low in $\delta^{13} \mathrm{C}$, higher food supply and availability of isotopically light carbon out of this source were expected to result in decreasing $\delta^{13} \mathrm{C}$ of the coral skeleton. However, the lowest feeding rates provided in the experiment were already $\sim 5$ times higher than what is naturally available to corals in situ. Grottoli (2002) therefore related the unexpected increase in skeletal $\delta^{13} \mathrm{C}$ (Fig. 5b) to enhanced nitrogen fertilization out of the extraordinary organic matter uptake and therefore increased photosynthetic activity.

Grottoli (2002) argued convincingly, that the measured variability of $\delta^{13} \mathrm{C}$ in her experiment was exclusively due to the light and feeding treatments. Her data cannot be due to kinetic fractionation effects as investigated by McConnaughey (1989). According to that model, oxygen and carbon isotopic composition of DIC formed by $\mathrm{CO}_{2}$ reactions in the calcifying fluid should both become more negative as $\mathrm{CO}_{2}$ hydroxylation increasingly dominates at higher $\mathrm{pH}$ (see also McConnaughey, 2003). Because $\delta^{13} \mathrm{C}$ in Grottoli's $(1999,2002)$ corals becomes more positive at higher light intensities, kinetic fractionation in response to a photosynthetically increased $\mathrm{pH}$ at the site of calcification cannot explain the observed isotopic trend. This argument is further corroborated by the fact that $\delta^{13} \mathrm{C}$ and $\delta^{18} \mathrm{O}$ of that data set are not correlated $\left(\delta^{18} \mathrm{O}=-4.17+\delta^{13} \mathrm{C} \times\right.$ $\left.0.02, \mathrm{n}=16, \mathrm{R}^{2}=0.003, p=0.84\right)$. The relationship between light and feeding treatments and Grottoli's (2002) experimental $\delta^{13} \mathrm{C}$ data is very well constrained and can be used to help interpret the $\delta^{11} \mathrm{~B}$ signal of these corals.

Unlike carbon, boron in seawater is very abundant relative to any potential biological needs. The distribution coefficient for $\mathrm{B}$ in corals, $\mathrm{D}_{\mathrm{B} \text { (coral) }}=\mathrm{B} / \mathrm{Ca}_{\text {coral }} / \mathrm{B} / \mathrm{Ca}_{\text {seawater }}$, is approximately 0.011 , where $\mathrm{B}_{\text {coral }} \sim 50 \mathrm{ppm}$ (i.e., $4.62 \mu \mathrm{mol} / \mathrm{g} \mathrm{CaCO}_{3}$ ), $\mathrm{B}_{\text {seawater }}=$ $416 \mu \mathrm{mol} \mathrm{kg}^{-1}$ (DOE, 1994) and $\mathrm{Ca}_{\text {seawater }} \sim 10 \mathrm{mmol} \mathrm{kg}^{-1}$. This value indicates that only a minute amount of $\mathrm{B}$ from seawater is incorporated into the coral skeleton and a potential vital effect on $\delta^{11} \mathrm{~B}$ would be clearly related to changes in $\mathrm{pH}$ at the site of coral calcification. The $\mathrm{pH}$-changes measured by Kühl et al. (1995) in the tissue of the coral Favia sp. were on the order of $\sim 0.8 \mathrm{pH}$ units for light intensities between 40 and $350 \mu \mathrm{mol}$ photons $\mathrm{m}^{-2} \mathrm{~s}^{-1}$. Al-Horani et al. (2003) found a similar range in the calcifying fluid of Galaxea fascicularis with $\mathrm{pH}$ dropping from 9.28 at $140 \mu \mathrm{mol}$ photons $\mathrm{m}^{-2} \mathrm{~s}^{-1}$ to 8.13 in complete darkness. These measured $\mathrm{pH}$ changes and Grottoli's $(1999,2002) \delta^{13} \mathrm{C}$ results will now be used to interpret coral $\delta^{11} \mathrm{~B}$ with regard to experimental light and feeding treatments and across habitat depth.

\subsection{Light and Feeding}

In contrast to Grottoli's (2002), $\delta^{13} \mathrm{C}$ data $\delta^{11} \mathrm{~B}$ does not show any significant light or feeding effects (Fig. 3). The lack of a systematic effect in $\delta^{11} \mathrm{~B}$ under the given conditions is not unreasonable. Comparison of the experimental light intensities with photosynthesis vs. irradiance (P-E) curves of coral-symbiont associations (e.g., Kühl et al., 1995) reveals that the onset of light saturation occurs around $300 \mu \mathrm{mol}$ photons $\mathrm{m}^{-2} \mathrm{~s}^{-1}$. Although slightly higher photosynthetic rates can be achieved until the symbiotic light harvesting complex is completely saturated (around 500-600 $\mu \mathrm{mol}$ photons $\mathrm{m}^{-2} \mathrm{~s}^{-1}$, e.g., Kühl et al., 1995), changes in photosynthesis and $\mathrm{pH}$ at the site of calcification are rather subtle. We propose these variations cannot be picked up with the boron isotope record. Analytical uncertainty in $\delta^{11} \mathrm{~B}$ is at least five times higher than in $\delta^{13} \mathrm{C}$ 


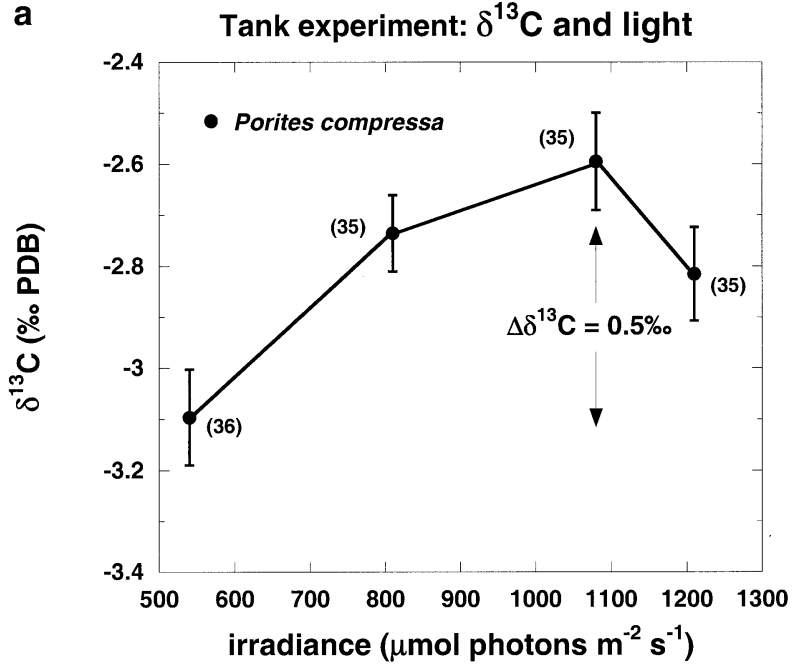

b

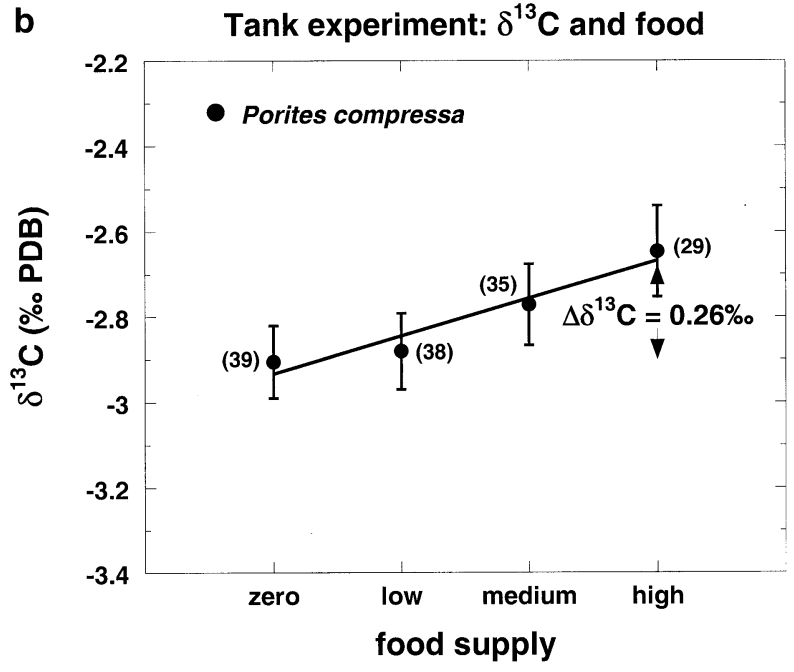

C

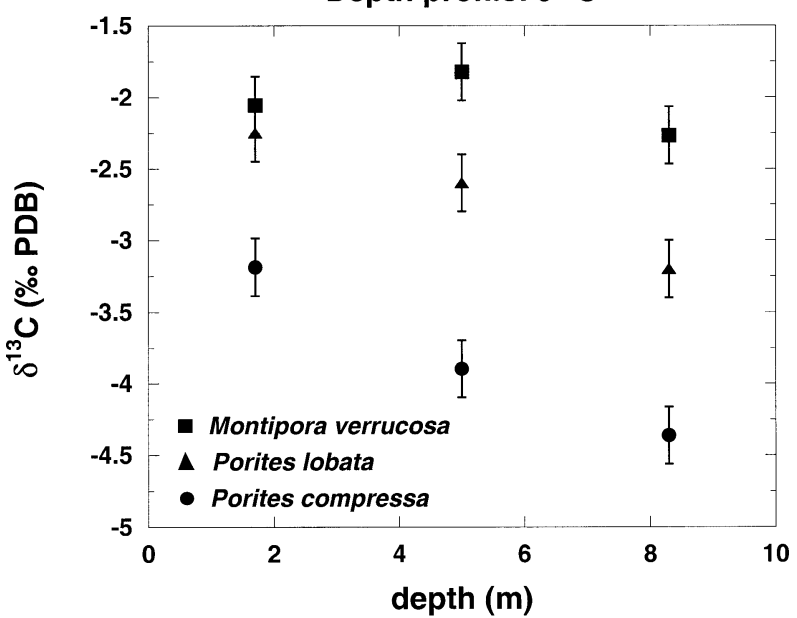

Fig. 5. Effect of symbiont photosynthetic activity on coral skeletal $\delta^{13} \mathrm{C}$ : Data support the idea that symbionts actively sequester ${ }^{12} \mathrm{C}$ and thereby enrich the carbon pool for skeletogenesis in ${ }^{13} \mathrm{C}$ relative to seawater $\delta^{13} \mathrm{C}$. Mean skeletal $\delta^{13} \mathrm{C}( \pm 1 \mathrm{sd})$ therefore increases at higher light intensities (a) and decreases with habitat depth (c). Relatively lighter $\delta^{13} \mathrm{C}$ at highest light intensity in (a) was attributed to a
( \pm 0.5 vs. $\pm 0.07 \%$ o, respectively) so that subtle changes in isotopic composition due to small changes in photosynthesis can be resolved with $\delta^{13} \mathrm{C}$ but not with $\delta^{11} \mathrm{~B}$.

\subsection{Depth Transect}

In their natural environment some corals experience much lower light intensities than provided in Grottoli's (2002) experiments. Since irradiance at depth was not measured during the experiment, we refer to light data which were monitored by the "Long-term Kaneohe Bay Monitoring Project" for the years 1999-2000. Photosynthetic active radiation (PAR) data for subsurface seawaters in South Kaneohe Bay are available online at http://www.hawaii.edu/cisnet. Water at Kaneohe Bay is not very clear and typical PAR values for the culture period August-November at this location are on the order of 100-200 $\mu \mathrm{mol}$ photons $\mathrm{m}^{-2} \mathrm{~s}^{-1}$ at $8 \mathrm{~m}$ depth and can occasionally drop as low as 30-70 $\mu \mathrm{mol}$ photons $\mathrm{m}^{-2} \mathrm{~s}^{-1}$. Compared to Kühl et al.'s (1995) P-E curve for Acropora sp. these irradiances are well below light saturation of the symbiont-host association. Although P-E curves for the species studied herein are not available to our knowledge, light levels below $200 \mu \mathrm{mol}$ photons $\mathrm{m}^{-2} \mathrm{~s}^{-1}$ are assumed not to be saturating and Grottoli's (1999) decreasing $\delta^{13} \mathrm{C}$ data support this assumption. However, neither coral species showed a significant decrease in $\delta^{11} \mathrm{~B}$ along the depth transect (Fig. 4) as would be expected if photosynthesis ceased at lower light intensities and if $\mathrm{pH}$ at the calcification site were closely related to symbiont photosynthetic activity. In fact, the deepest $M$. verrucosa sample shows slightly elevated $\delta^{11} \mathrm{~B}$ compared to the shallower samples. The lack of a photosynthesis effect on $\delta^{11} \mathrm{~B}$ is best illustrated in Figure 5, where $\delta^{11} \mathrm{~B}$ of the laboratory (Fig. 6a) and field experiments (Fig. 6b) is plotted versus the respective $\delta^{13} \mathrm{C}$ data.

At this point it is unclear why the supposed changes in photosynthetic rate apparently do not affect the $\mathrm{pH}$-gradient between the site of calcification and ambient seawater. Physiological adaptation to lower light intensities, for instance the creation of a more efficient light harvesting complex (e.g., Gattuso, 1985; IgelsiasPrieto and Trench, 1994; Beer et al., 1998), may account for the lack of a depth effect in $\delta^{11} \mathrm{~B}$. However, the interactions between photosynthesis and calcification in corals are poorly understood (see, for review, Gattuso et al., 1999) and although it is widely accepted now that coral calcification is higher in light than in darkness, maximum linear extension of the corals studied herein did not always decrease with depth (Grottoli, 1999) but significantly decreased at higher light intensities (Grottoli, 2002). Although calcification rates and linear skeletal extension may not be synonymous, this growth pattern seems to contradict the expectation. Photosynthesis and calcification may be decoupled or at least may not covary linearly. Our data may also suggest that $\mathrm{pH}$ at the calcification site is not closely related to photosynthesis. The $\mathrm{pH}$ amplitude at the site of calcification in foraminifera $(\Delta \mathrm{pH} \approx 0.9$

photoinhibition effect. Extraordinarily high food supply during experiments for (b) resulted in unexpected nitrogen fertilization which increased photosynthesis. See text for details. All plots modified after Grottoli (2002) (Fig. 5a and b) and Grottoli (1999) (Fig. 5c). The sample sizes of each mean are given in brackets. 
a
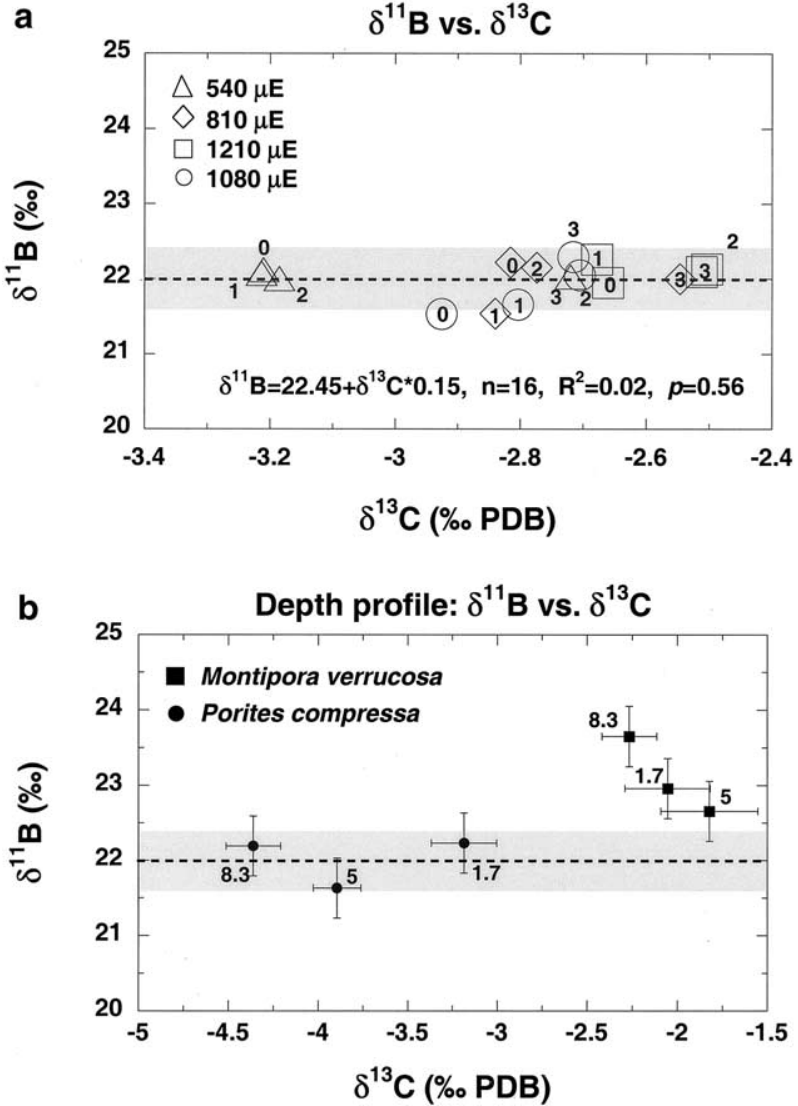

Fig. 6. $\delta^{11} \mathrm{~B}$ vs. $\delta^{13} \mathrm{C}$ of tank experiments (a) and depth profile (b). Values are averages of all available data. Numbers in (a) indicate feeding rates, i.e. $0=$ zero, $1=$ low, $2=$ medium and $3=$ high feeding rate. Numbers in (b) indicate waterdepth (m). Error bars in (a) were omitted for better comparability of the data but are similar to (b). As already anticipated by the lack of light, food and depth effects, no correlation exists between $\delta^{11} \mathrm{~B}$ and $\delta^{13} \mathrm{C}$, indicating that the vital effect responsible for $\delta^{13} \mathrm{C}$ variability is either too small to be resolved with $\delta^{11} \mathrm{~B}$ or that photosynthesis and $\mathrm{pH}$ at the site of calcification are not closely related. Gray bars indicate $1 \mathrm{sd}( \pm 0.4 \%$ o $)$ of the average $\delta^{11} \mathrm{~B}_{P \text {. compressa }}$ from the tank experiments.

units, Rink et al., 1998) and corals is comparable $(\Delta \mathrm{pH} \approx 1.1$ units, Al-Horani et al., 2003) and Hönisch et al. (2003) have measured $\Delta \delta^{11} \mathrm{~B} \approx-1.5$ to $-2.2 \%$ ofor $O$. universa grown at 20 $\mu \mathrm{mol}$ photons $\mathrm{m}^{-2} \mathrm{~s}^{-1}$ relative to individuals grown at $320 \mu \mathrm{mol}$ photons $\mathrm{m}^{-2} \mathrm{~s}^{-1}$. The measured $\delta^{11} \mathrm{~B}$ offset for $O$. universa translates into an integrated $\Delta \mathrm{pH} \approx 0.2-0.3 \mathrm{pH}$ units, which is in good agreement with day/night calcification rates and symbiont photosynthetic rates at the given light intensities (Hönisch et al., 2003). Similar culture experiments have also determined the light effect on $\Delta \delta^{13} \mathrm{C} \approx 2 \%$ in $O$. universa for irradiance levels between 8 and $540 \mu \mathrm{mol}$ photons $\mathrm{m}^{-2} \mathrm{~s}^{-1}$ (Spero and Lea, 1993). This variation compares quite well to $\Delta \delta^{13} \mathrm{C} \approx 1.2 \%$ in $P$. compressa grown along a depth transect where light levels varied between 30 and $1080 \mu \mathrm{mol}$ photons $\mathrm{m}^{-2} \mathrm{~s}^{-1}$ (http://www.hawaii. edu/cisnet, Grottoli, 1999). This comparison demonstrates that the analytical uncertainty of $\delta^{11} \mathrm{~B}$ may be small enough to allow for detection of integrated $\mathrm{pH}$ variations in the coralline microenvironment. The fact that $75 \%$ of our $\delta^{11} \mathrm{~B}$ data for $P$. compressa lie within $\pm 0.4 \%$ of the overall average of $22.0 \%$ o, and that no significant light, feeding or depth effects could be observed, may suggest that the lack of $\delta^{11} \mathrm{~B}$ variability needs to be taken at face value. Since the $\left[\mathrm{Ca}^{2+}\right]$ and $\mathrm{pH}$ variations measured by $\mathrm{Al}-\mathrm{Horani}$ et al. (2003) in the calcifying fluid were clearly triggered by illumination, our data may thus suggest that once photosynthesis (or some related parameter such as $\mathrm{O}_{2}$ or $\mathrm{CO}_{2}$ level) passes a threshold value and activates the $\mathrm{Ca}^{2+}$-ATPase, the enzyme system works at a constant rate that is independent of light level and photosynthesis rate. The remarkable point is, however, that the $\mathrm{pH}$ offset between the site of calcification and ambient seawater appears to remain constant at varying seawater $\mathrm{pH}$. If that were not the case, the $\delta^{11} \mathrm{~B}$ offset between theoretical $\mathrm{B}(\mathrm{OH})_{4}^{-}$curve and empirical calibrations would not be as constant as it is (Fig. 2b).

Until coral physiology is understood in more detail, correct prediction of changes in carbonate chemistry in the microenvironment of a coral is difficult, if not impossible. Unfortunately, Al-Horani et al. (2003) did not measure $\mathrm{pH}$ at the site of calcification at various light intensities and Kühl et al.'s (1995) data are restricted to the polyp surface where $\mathrm{pH}$ variations are probably determined by the same processes as in foraminifera. If $\mathrm{pH}$ at the site of calcification is related to photosynthetic rates at all, the effect must be so small that it cannot be resolved with the current analytical uncertainty of $\delta^{11} \mathrm{~B}$. The uniformity of our $\delta^{11} \mathrm{~B}$ data across a broad range of light (from 1210 down to 30-70 $\mu$ mol photons $\mathrm{m}^{-2} \mathrm{~s}^{-1}$ ) and feeding treatments supports the idea that $\delta^{11} \mathrm{~B}$ in corals is a reliable paleo-pH recorder. Symbiont photosynthetic activity and feeding activity do not compromise the $\delta^{11} \mathrm{~B}-\mathrm{pH}$ record of zooxanthellate corals.

\subsection{The Fanning Island Coral Record}

Following our results, seasonal changes in $\delta^{11} \mathrm{~B}$ as observed by Hemming et al. (1998) cannot be due to changes in symbiont photosynthetic activity during seasons of high insolation. It appears more likely that the carbonate chemistry of the bulk seawater in which the coral was bathed changed seasonally. There are two possibilities that could cause such seasonal changes. First of all, the coexistence of corals and macroalgae is known to modify bulk seawater carbonate chemistry significantly (Gattuso et al., 1993, 1996; Frankignoulle et al., 1996; Bates et al., 2001; Bates, 2002) and local seasonal changes may occur due to seasonal variations in the net balance between coral calcification and macro algal primary productivity (Bates, 2002). The second explanation involves seasonal changes on a regional scale: Fanning Island is located in the equatorial Pacific at $3.9^{\circ} \mathrm{N}$ and $159.4^{\circ} \mathrm{W}$. According to Taft and Kessler (1991) the major ocean currents annually shift latitudinally over this site. On average from May to July Fanning Island lies in the path of the South Equatorial Current (SEC) and during November-January in the North Equatorial Counter Current (NECC). Whereas upwelling supplies the SEC with high nutrient concentrations and high $\mathrm{PCO}_{2}(\sim 435 \mathrm{ppm})$, the NECC is nutrient depleted and $p \mathrm{CO}_{2}$ is in equilibrium with the atmosphere ( $350 \mathrm{ppm})$ (Archer et al., 1997). Hemming et al.'s (1998) 2-yr coral record displays average $\delta^{13} \mathrm{C}$ and $\delta^{11} \mathrm{~B}$ values of $-2.7 \%$ and $24.6 \%$ in the low density bands, respectively $-1.65 \%$ and $25.9 \%$ in the high density bands. Although a difference of approximately $-1 \%$ in $\delta^{13} \mathrm{C}_{\text {DIC }}$ between the NECC and the SEC appears rather high, the heavier $\delta^{11} \mathrm{~B}$ of the high density bands translates into a +0.1 unit higher $\mathrm{pH}$ value 
(using the calibration curve for $P$. cylindrica in Fig. 2, this study). In order to demonstrate that this value is in agreement with the difference in $\mathrm{pH}$ between the two water masses, we would need seasonal carbonate chemistry data (i.e., two parameters of the carbonate system such as alaklinity and DIC) from Fanning Island. To our knowledge such specific data are presently not available. As a first approximation we therefore used alkalinities and total dissolved inorganic carbon (DIC) data from WOCE station P16 (available online at http://whpo.ucsd. edu/data/onetime/pacific/p16/p16c/index.htm) at $3^{\circ} \mathrm{N} 151^{\circ} \mathrm{W}$ and $5^{\circ} \mathrm{N} 151^{\circ} \mathrm{W}$ to calculate surface $\mathrm{pH}$ and $p \mathrm{CO}_{2}$ data for that region. Water samples for those data were collected in September 1991 and represent the transition from summer to winter oceanographic setting. According to Taft and Kessler's (1991) work we assumed that the conditions present at $5^{\circ} \mathrm{N}$ would soon shift southwards and replace the SEC. Using Lewis and Wallace's (1998) CO2SYS program to calculate $\mathrm{pH}$ (on the SW scale) and $p \mathrm{CO}_{2}$ yields 8.07 and 347 ppm for $5^{\circ} \mathrm{N}$, respectively 8.01 and $418 \mathrm{ppm}$ at $3^{\circ} \mathrm{N}$. Given the analytical uncertainties of $\delta^{11} \mathrm{~B}$, the difference in $\mathrm{pH}$ between the two watermasses. $(\Delta \mathrm{pH}=0.06)$ is in reasonable agreement with the coral $\mathrm{pH}$ record $(\Delta \mathrm{pH}=0.1) . p \mathrm{CO}_{2}$ data from near Fanning Island yielded $416 \mathrm{ppm}$ in June $2003\left(3.96^{\circ} \mathrm{N}, 163.7^{\circ} \mathrm{W}\right)$ and $359 \mathrm{ppm}$ in October $1998\left(3.9^{\circ} \mathrm{N}, 162.8^{\circ} \mathrm{W}\right)$ (Takahashi et al., 2004) and thus confirm that $\Delta p \mathrm{CO}_{2}=67 \mathrm{ppm}$ (June-October) is on the same order as the regional WOCE data from $\mathrm{P} 16,8^{\circ}$ further to the east $\left(\triangle \mathrm{PCO}_{2} \sim 70 \mathrm{ppm}\right)$. Consequently, the $\delta^{11} \mathrm{~B}$ of the high density bands of this coral seem to reflect the $\mathrm{pH}$ of the NECC, whereas the broader low density bands record the chemical properties of the SEC.

\section{CONCLUSIONS}

Empirical calibration of the two corals $P$. cylindrica and $A$. nobilis confirms that corals faithfully reflect variations in seawater $\mathrm{pH}$. There are significant but constant offsets between these two species and relative to the theoretical $\mathrm{B}(\mathrm{OH})_{4}^{-}$curve. Similar offsets were found between $P$. compressa and $M$. verrucosa. Growth under various light conditions and at different depths did not result in measurable differences of the boron isotopic composition. This is in contrast to the response of the carbon isotopic composition of the same corals studied herein, which revealed a significant effect from symbiont photosynthetic activity due to light, feeding and habitat depth. The fact that $\delta^{11} \mathrm{~B}$ does not change under varying light levels suggests that $\mathrm{pH}$ variations at the site of calcification are likely small relative to the $\mathrm{pH}$-dependent isotopic fractionation and the present analytical uncertainty. Reinterpretation of the Fanning Island coral record from an oceanographic point of view reveals a promising agreement between seawater-pH and coralline $\delta^{11} \mathrm{~B}$. These results promise a great benefit of using corals in reconstructing paleo-pH.

Acknowledgments - We are especially grateful to B. Vitale for helping to maintain our old mass spectrometer in good condition. Laboratory assistance by J. Munster and J. Cole is greatly appreciated. We thank the Tropical Biosphere Research Centre of Ryukyus, Japan, the Hawaii Institute of Marine Biology on Coconut Island, Hawaii, and the many field assistants who made this work possible. F. Cox and P. L. Jokiel helped in describing the underwater light environment at Kaneohe Bay, Hawaii. Comments provided by T. A. McConnaughey, M. Reuer, D.W. Lea and an anonymous reviewer improved the manuscript substan- tially. We acknowledge financial support from the National Science Foundation (OCE 00-83061) as well as funding to A.G. Grottoli by the EPA STAR fellowship (U-914955-01-0) and the Mellon Foundation.

Associate editor: D. W. Lea.

\section{REFERENCES}

Al-Horani F. A., Al-Moghrabi S. M., and de Beer D. (2003) The mechanism of calcification and its relation to photosynthesis and respiration in the scleractinian coral Galaxea fascicularis. Mar. Biol. 142, 419-426.

Amat A. (2000) Croissance corallienne et variations du $\mathrm{CO}_{2}$ atmosphérique: Implications biologiques et climatiques. Thesis. Université Pierre et Marie Curie.

Archer D., Aiken J., Balch W., Barber W., Dunne J., Flament P., Gardner W., Garside C., Goyet C., Johnson E., Kirchman D., McPhaden M., Newton J., Peltzer E., Welling L., White J., and Yoder J. (1997) A meeting place of great ocean currents: shipboard observations of a convergent front at $2^{\circ} \mathrm{N}$ in the Pacific. Deep-Sea Res. II 44(9-10), 1827-1849.

Bates N. R. (2002) Seasonal variability of the effect of coral reefs on seawater $\mathrm{CO}_{2}$ and air-sea $\mathrm{CO}_{2}$ exchange. Limnol. Oceanogr. 47(1), $43-52$.

Bates N. R., Samuels L., and Merlivat L. (2001) Biogeochemical and physical factors influencing seawater $f \mathrm{CO}_{2}$ and air-sea $\mathrm{CO}_{2}$ exchange on the Bermuda coral reef. Limnol. Oceanogr. 46(4), 833846.

Beer S., Ilan M., Eshel A., Weil A., and Brickner I. (1998) Use of pulse amplitude modulated (PAM) fluorometry for in situ measurements of photosynthesis in two Red Sea faviid corals. Mar. Biol. 131, $607-612$.

Dickson A. G. (1990) Standard potential of the reaction: $\mathrm{AgCl}(\mathrm{s})+$ $1 / 2 \mathrm{H}_{2}(\mathrm{~g})=\mathrm{Ag}(\mathrm{s})+\mathrm{HCl}(\mathrm{aq})$, and the standard acidity constant of the ion $\mathrm{HSO}_{4}^{-}$in synthetic seawater from 273.15 to $318.15 \mathrm{~K}$ J. Chem. Thermodyn. 22, 113-127.

Dickson A. G. and Millero F. J. (1987) A comparison of the equilibrium constants for the dissociation of carbonic acid in sawater media. Deep-Sea Res. 34, 1733-1743.

DOE. (1994) Handbook of Methods for the Analysis of the Various Parameters of the Carbon Dioxide System in Seawater. Department of Energy. ORNL/CDIAC-74. Version 2.

Fischer H., Wahlen M., Smith J., Mastroianni D., and Deck B. (1999) Ice core records of atmospheric $\mathrm{CO}_{2}$ around the last three glacial terminations. Science 283, 1712-1714.

Frankignoulle M., Gattuso J.-P., Biondo R., Bourge I., Copin-Montégut G., and Pichon M. (1996) Carbon fluxes in coral reefs. II. Eulerian study of inorganic carbon dynamics and measurement of air-sea $\mathrm{CO}_{2}$ exchanges. Mar. Ecol. Prog. Ser. 145, 123-132.

Furla P., Galgani I., Durand I., and Allemand D. (2000) Sources and mechanisms of inorganic carbon transport for coral calcification and photosynthesis. J. Exp. Biol. 203, 3445-3457.

Gattuso J.-P. (1985) Features of depth effects on Stylophora pistillata, an hermatypic coral in the Gulf of Aqaba (Jordan, Red Sea). Fifth International Coral Reef Congress, 95-100.

Gattuso J.-P., Pichon M., Delesalle B., and Frankignoulle M. (1993) Community metabolism and air-sea $\mathrm{CO}_{2}$ fluxes in a coral reef ecosystem (Moorea, French Polynesia). Mar. Ecol. Prog. Ser. 96, 259-267.

Gattuso J.-P., Pichon M., Delesalle B., Canon C., and Frankignoulle M. (1996) Carbon fluxes in coral reefs. I. Langranian measurement of community metabolism and resulting air-sea $\mathrm{CO}_{2}$ disequilibrium. Mar. Ecol. Prog. Ser. 145, 109-121.

Gattuso J.-P., Allemand D., and Frankignoulle M. (1999) Photosynthesis and calcification at cellular, organismal and community levels in coral reefs: A review on interactions and control by carbonate chemistry. Am. Zool. 39, 160-183.

Gattuso J.-P., Reynaud-Vaganay S., Furla P., Romaine-Lioud S., and Jaubert J. (2000) Calcification does not stimulate photosynthesis in the zooxanthellate scleractinian coral Stylophora pistillata. Limnol. Oceanogr. 45(1), 246-250. 
Goreau T. J. (1977) Coral skeletal chemistry: Physiological and environmental regulation of stable isotopes and trace metals in Montastrea annularis. Proc. R. Soc. Lond. B 196, 291-315.

Grottoli A. G. (1999) Variability of stable isotopes and maximum linear extension in reef-coral skeletons at Kaneohe Bay, Hawaii. Mar. Biol. 135, 437-449.

Grottoli A. G. (2002) Effect of light and brine shrimp on skeletal $\delta^{13} \mathrm{C}$ in the Hawaiian coral Porites compressa: A tank experiment. Geochim. Cosmochim. Ac. 66(11), 1955-1967.

Grottoli A. G. and Wellington G. M. (1999) Effect of light and zooplankton on skeletal $\delta^{13} \mathrm{C}$ values in the eastern Pacific corals Pavona clavus and Pavona gigantea. Coral Reefs 18, 29-41.

Hemming N. G. and Hanson G. N. (1992) Boron isotopic composition and concentration in modern marine carbonates. Geochim. Cosmochim. Acta 56, 537-543.

Hemming N. G. and Hanson G. N. (1994) A procedure for the isotopic analysis of boron by negative thermal ionization mass spectrometry. Chem. Geol. 114, 147-156.

Hemming N. G., Reeder R. J., and Hanson G. N. (1995) Mineral-fluid partitioning and isotopic fractionation of boron in synthetic calcium carbonate. Geochim. Cosmochim. Ac. 59(2), 371-379.

Hemming N. G., Guilderson T. P., and Fairbanks R. G. (1998) Seasonal variations in the boron isotopic composition of a coral: A productivity signal? Global Biogeochem. Cy. 12(4), 581-586.

Hönisch B., Bijma J., Russell A. D., Spero H. J., Palmer M. R., Zeebe R. E., and Eisenhauer A. (2003) The influence of symbiont photosynthesis on the boron isotopic composition of foraminifera shells. Mar. Micropaleontol. 49, 87-96.

Iglesias-Prieto R. and Trench R. K. (1994) Acclimation and adaptation to irradiance in symbiotic dinoflagellates. I. Responses of the photosynthetic unit to changes in photon flux density. Mar. Ecol. Prog. Ser. 113, 163-175.

Jørgensen B. B., Erez J., Revsbech N. P., and Cohen Y. (1985) Symbiotic photosynthesis in a planktonic foraminiferan, Globigerinoides sacculifer (Brady), studied with microelectrodes. Limnol. Oceanogr. 30(6), 1253-1267.

Kakihana H., Kotaka M., Satoh S., Nomura M., and Okamoto M. (1977) Fundamental studies on the ion-exchange of boron isotopes. Bull. Chem. Soc. Jpn. 50, 158-163.

Kühl M., Cohen Y., Dalsgaard T., Jørgensen B. B., and Revsbech N. P. (1995) Microenvironment and photosynthesis of zooxanthellae in scleractinian corals studied with microsensors for $\mathrm{O}_{2}, \mathrm{pH}$ and light. Mar. Ecol. Prog. Ser. 117, 159-172.

Lewis E. and Wallace D. W. R. (1998) Program developed for $\mathrm{CO}_{2}$ system calculations. ORNL/CDIAC-105.

Marshall A. T. (1996) Calcification in hermatypic and ahermatypic corals. Science 271, 637-639.

McConnaughey T. (1989) ${ }^{13} \mathrm{C}$ and ${ }^{18} \mathrm{O}$ isotopic disequilibrium in biological carbonates: 1. Patterns. Geochim. Cosmochim. Acta 53, 151-162.

McConnaughey T. A. (2003) Sub-equilibrium oxygen-18 and carbon-13 levels in biological carbonates: Carbonate and kinetic models. Coral Reefs 22(4), 216-327.

McConnaughey T. A. and Whelan J. F. (1997) Calcification generates protons for nutrient and bicarbonate uptake. Earth-Sci. Rev. 42, 95-117.

Mehrbach C., Culberson C. H., Hawley J. E., and Pytkowicz R. M. (1973) Measurement of the apparent dissociation constants of carbonic acid in seawater at atmospheric pressure. Limnol. Oceanogr. 18, 897-907.

Neftel A., Oeschger H., Schwander J., Stauffer B., and Zumbrunn R. (1982) Ice core sample measurements give atmospheric $\mathrm{CO}_{2}$ content during the past 40,000 yr. Nature 295, 220-223.
Palmer M. R., Spivack A. J., and Edmond J. M. (1987) Temperature and $\mathrm{pH}$ controls over isotopic fractionation during adsorption of boron on marine clay. Geochim. Cosmochim. Acta 51, 2319-2323.

Palmer M. R., Pearson P. N., and Cobb S. J. (1998) Reconstructing past ocean pH-depth profiles. Science 282, 1468-1471.

Petit J. R., Jouzel J., Raynaud D., Barkov J. M., Barnola J. M., Basile I., Bender M., Chappellaz J., Davis M., Delaygue G., Delmotte M., Kotlyakov V. M., Legrand M., Lipenkov V. Y., Lorius C., Pepin L., Ritz C., Saltzman E., and Stievenard M. (1999) Climate and atmospheric history of the past 420,000 years from the Vostok ice core, Antarctica. Nature 399, 429-436.

Reynaud S., Hemming N. G., Juillet-Leclerc A., and Gattuso J.-P. (in press) Effect of $p \mathrm{CO}_{2}$ and temperature on the boron isotopic composition of a zooxanthellate coral: Acropora sp. Coral Reefs.

Reynaud-Vaganay S., Gattuso J.-P., Cuif J.-P., Jaubert J., and JuilletLeclerc A. (1999) A novel culture technique for scleractinian corals: application to investigate changes in skeletal $\delta^{18} \mathrm{O}$ as a function of temperature. Mar. Ecol. Prog. Ser. 180, 121-130.

Rink S., Kühl M., Bijma J., and Spero H. J. (1998) Microsensor studies of photosynthesis and respiration in the symbiotic foraminifer $\mathrm{Or}$ bulina universa. Mar. Biol. 131(4), 583-595.

Sanyal A., Hemming N. G., Hanson G. N., and Broecker W. S. (1995) Evidence for a higher $\mathrm{pH}$ in the glacial ocean from boron isotopes in foraminifera. Nature 373, 234-236.

Sanyal A., Hemming N. G., Broecker W. S., Lea D. W., Spero H. J., and Hanson G. N. (1996) Oceanic pH control on the boron isotopic composition of foraminifera: Evidence from culture experiments. Paleoceanography 11(5), 513-517.

Sanyal A., Nugent M., Reeder R. J., and Bijma J. (2000) Seawater pH control on the boron isotopic composition of calcite: Evidence from inorganic calcite precipitation experiments. Geochim. Cosmochim. Ac. 64(9), 1551-1555.

Sanyal A., Bijma J., Spero H. J., and Lea D. W. (2001) Empirical relationship between $\mathrm{pH}$ and the boron isotopic composition of $G$. sacculifer: Implications for the boron isotope paleo-pH proxy. Paleoceanography 16(5), 515-519.

Spero H. J. and Lea D. W. (1993) Intraspecific stable isotope variability in the planktic foraminifera Globigerinoides sacculifer: Results from laboratory experiments. Mar. Micropaleontol. 22, 221-234.

Spivack A. J., You C.-F., and Smith H. J. (1993) Foraminiferal boron isotope ratios as a proxy for surface ocean $\mathrm{pH}$ over the past $21 \mathrm{Myr}$. Nature 363, 149-151.

Taft B. A. and Kessler W. S. (1991) Variations of zonal currents in the Central Tropical Pacific during 1970 to 1987: Sea level and dynamic height measurements. J. Geophys. Res. 96(C7), 1259912618.

Takahashi T., Sutherland S. C., Sweeney C., and Newberger T. (2004) Surface water $p \mathrm{CO}_{2}$ during R/V Nathaniel Palmer Cruise 98/6 and 03/4. URL:www.1deo.columbia.edu/CO2

Wolf-Gladrow D., Bijma J., and Zeebe R. E. (1999) Model simulation of the carbonate chemistry in the microenvironment of symbiont bearing foraminifera Mar. Chem. 64, 181-198.

Zeebe R. E., Sanyal A., Ortiz J. D., and Wolf-Gladrow D. A. (2001) A theoretical study of the kinetics of the boric acid-borate equilibrium in seawater. Mar. Chem. 74(2), 113-124.

Zeebe R. E. and Wolf-Gladrow D. A. (2001) $\mathrm{CO}_{2}$ in Seawater: Equilibrium, Kinetics, Isotopes. Elsevier.

Zeebe R. E., Wolf-Gladrow D. A., Bijma J., and Hönisch B. (2003) Vital effects in foraminifera do not compromise the use of $\delta^{11} \mathrm{~B}$ as a paleo-pH indicator: Evidence from modeling. Paleoceanography 18(2), 1043. 